\title{
Pacific Discourses About Cultural Heritage and Its Protection: An Introduction
}

\author{
Toon van Meijl*
}

\begin{abstract}
Any theory of culture must include the concept of the dialectical interaction between culture and something that is not culture.
\end{abstract}

E.P. Thompson, The Long Revolution, p. 33

\begin{abstract}
The articles collected in this special issue aim at addressing the debate about the protection and use of cultural heritage in the Pacific within the context of globalization. Contributions aim specifically at analyzing the tension that exists between, on the one hand, political, legal and economic discourses of Pacific peoples who wish to retain control and who seek protection of the use of their cultural heritage, and, on the other hand, the view of others arguing that it is in the interest of the general public to lift as many embargos as possible in order to stimulate research and to increase economic growth. All authors approach the subject of cultural and intellectual property rights as a discourse, with specific attention for the concepts of property and ownership, particularly in relation to cultural heritage and
\end{abstract}

\footnotetext{
* University of Nijmegen. Email: t.vanmeijl@ru.nl

ACKNOWLEDGEMENTS: Contributions to this special issue have been developed in the course of a series of workshops held at the annual meetings of the Association for Social Anthropology in Oceania. In 2005 an informal session was held in Lihu'e at Kaua'i, Hawaii; in 2006 a working session was held in San Diego, California; and in 2007 a symposium was held in Charlottesville, Virginia. For a variety of reasons, not every article presented at any of these sessions made it into this special issue, but we remain grateful to the following people for their interest and contributions to the various sessions: Nick Bainton, John Barker, Jane Barnwell, Anne Chambers, Keith Chambers, Haidy Geismar, Sam Kaima, Jacob Simet, and Nicholas Thieberger. I am especially indebted to Malia Talakai for co-organizing the sessions and for her stimulating work on the protection of cultural property in Tonga. I also thank Alex Golub for drawing my attention to the early work by Robert Lowie, and Michael Goldsmith for his comments on an earlier version of this introduction. Finally, I would like to acknowledge the contribution to my work on cultural and intellectual property by Mark Busse, Manuka Henare, 'Okusitino Māhina, and Owen Morgan, with whom we hope to initiate a large, comparative research program on the issues set out in this special issue.
} 
cultural knowledge; the potential benefits of property; appropriate protection mechanisms; the complexities of the discourses about rights, especially property rights; the appropriation of property or its misappropriation, often associated with what is freely available in the public domain; and, finally, the use of intellectual property as either a form of enclosure or as a form of ethnic boundary.

Culture is increasingly represented as a resource that can be claimed as property of which the claimants are the intellectual owners. ${ }^{1}$ In Europe, for example, the cultural practices associated with the production of champagne, feta cheese, and tokai wines have recently been recognized as the intellectual property of French, Greek, and Hungarian farmers, so their artisanal products are protected against imitations by cultural aliens. It is widely accepted that this casting of culture must be understood in the context of the worldwide rise of neoliberal economics. However, economic benefits are not the only motivations for ownership claims of cultural practices and products. Thus, a restaurateur in Amsterdam was forced to change the name of his new premises, which he had branded "Moko," referring to Māori tattoo designs, because the indigenous population of New Zealand considers the label moko a spiritual treasure that must not be alienated from its cultural roots. This concern with culture is usually articulated by peoples who feel they are being marginalized, especially those who are tagged as indigenous. They fear the loss of their culture and traditions or control over their culture and associated symbols that express their identity. Ownership claims of culture are therefore also significant for symbolic reasons, if not for political reasons. ${ }^{2}$

Obviously, the politicization of culture is also intertwined with the process of globalization, which in contrast to earlier expectations has incited a large-scale revival of cultural heritage at local levels. ${ }^{3}$ Paradoxically, however, cultural traditions of small-scale societies are increasingly disseminated around the world following innovations in information and communication technologies. This globalization of local traditions, in turn, provokes the desire to control culture, which is particularly widespread in societies that fear their cultural heritage is under threat. ${ }^{4}$ Interestingly, contemporary representations of culture in this context frequently involve a reification that reinforces a relatively strict demarcation of cultural and ethnic boundaries. People who experience their culture and identity as endangered by global forces increasingly aim at regulating, managing, or limiting either the inflow of culturally foreign symbols, considered impure, or the outflow of culturally indigenous symbols, considered a form of piracy or theft. ${ }^{5}$ Needless to say, the development of "proprietary identities," as Simon Harrison describes them, generates a certain degree of tension between different communities.

The tension that emerges from the global debate about the ownership of cultural heritage constitutes the common point of departure of the contributions to this special issue on the discourse of cultural and intellectual property rights in 
the Pacific. To be sure, a tension of sorts is the focus in this issue, between different communities as well as between culture and politics. ${ }^{6}$ The tension between culture and politics in the strategic context of the protection of cultural heritage is often misconstrued, because the debate takes place in legal terms. The legalization of culture is a relatively new global process that mystifies the intricate relationship between culture and politics, because the explication of culture in terms of law leaves out the dimension of moral and political agency. ${ }^{7}$ To deconstruct the juridification of the political goal to maintain and regain control of culture, we opted to use the concept of discourse in our analysis and clarification of the various dimensions of the discussion. The concept of discourse is useful for the analysis of the political context surrounding the protection of cultural properties, because it directs the attention away from the truth value of specific statements. Instead, it channels the focus onto the rhetorical devices used to substantiate arguments and which enable issues or certain constellations of values to pass from one discourse into another (i.e., from culture into politics). ${ }^{8}$ Thus, we address debates revolving around the legal protection of culture in Pacific societies by situating them in a multidimensional context characterized by conflicting interests between different groupings, included or excluded in the competing claims of cultural and intellectual property.

All contributors to this issue also share a common background in social and cultural anthropology with ethnographic expertise in the Pacific region. In anthropology the Pacific was traditionally known as the laboratory of the discipline, ${ }^{9}$ because the conditions for comparative research are outstanding. The region was settled relatively recently in evolutionary history. Consequently, cultural similarities between different societies are striking, whereas dissimilarities are equally interesting because the various societies have developed rather autonomously on the various islands. Divergent experiences during the colonial era have reinforced cultural variation in the region. ${ }^{10}$

In the context of the debate about cultural property, the Pacific region is interesting, because it leads the development of sui generis legislation to protect traditional knowledge and expressions of culture against misuse and misappropriation by others. A consequence of this development, however, is the reinforcement of boundaries between communities that counterpoises the irreversible globalization process, which brings about social and political tension, both within and between societies. At a theoretical level this tension is related to the epistemological dilemma between cultural relativism and universalism, which has also reacquired significance in the related debate about the human rights of indigenous peoples, such as the Australian Aborigines, the New Zealand Māori, and the Kanaka Maoli, the first inhabitants of the Hawaiian archipelago. ${ }^{11}$ Our goal is to address this tension by comparing and contrasting Pacific strategies for the protection of their cultural heritage with other third-party interests and the interests of the general public further afield. Before going into further detail about the Pacific, however, it is necessary to clarify a few more theoretical premises and political and strategic developments guiding the contributions to this special issue. 


\section{CULTURAL HERITAGE AND INDIGENOUS KNOWLEDGE SYSTEMS}

Cultural traditions and the knowledge that is associated with them are often conveniently represented as heritage. Clifford has defined heritage as "self-conscious tradition ... asserted against historical experiences of loss." ${ }^{12}$ This definition can be further specified by clarifying that the term self-conscious is understood in the sense of revitalized and revalued, whereas loss is considered particularly in the form of (mis) appropriation. Experiences of (mis) appropriation are probably most significant in societies of indigenous peoples who are trying to come to terms with a colonial history of dispossession. ${ }^{13}$ For that reason, too, over the past 15 years claims of cultural and intellectual property have become of particular concern in counterhegemonic discourses of indigenous peoples and other small-scale societies that experience their way of life as under threat. ${ }^{14}$

The first claims of cultural property rights in the strict sense of the term emerged during the Uruguay Round of negotiations for a revision of the General Agreement on Tariffs and Trade (GATT) aiming at a further reduction of barriers for trade and investment demanded by the globalization process. During these negotiations, intellectual property rights became one of the new areas of concern, because the United States and the European Community argued that goods of developed countries contain a large intellectual property investment that is inadequately protected in developing countries that do not have a strong regime for the protection of intellectual property rights. Eventually, the new GATT of 1994 included an agreement on Trade Related Aspects of Intellectual Property Rights (TRIPS), which set down some minimum standards for intellectual property regulation but also stipulated some conditions under which certain materials or innovations may be excluded from intellectual property regimes.

The TRIPS agreement triggered protest from small-scale, postcolonial societies around the world, because it opened up the avenue to the exploitation of their traditional knowledge systems for transnational corporations. ${ }^{15}$ These companies increasingly recognize so-called indigenous knowledge about genetic resources, exotic species of flora and fauna, ecosystems, and landscapes as bonanzas for economic investments and technological innovations, especially by pharmaceutical industries, bioprospecting businesses, and mining companies. The global trend of exploring indigenous knowledge systems for commercial purposes provided a range of postcolonial societies with an important incentive to campaign worldwide for the recognition of their human rights, including the right to self-determination. ${ }^{16}$ They claim that the enhanced accessibility of traditional knowledge systems violates their right to self-determination, which includes the autonomy to make decisions about the use of traditional knowledge. The first highlight of this campaign was the proclamation of the year 1993 as the United Nations Year for Indigenous Peoples when a Declaration on the Rights of Indigenous Peoples was drafted. This declaration was finally adopted in 2007, but 4 major countries voted against it (Australia, Canada, New Zealand, and the United States), while 11 other countries 
abstained from voting. In final form the declaration nevertheless states explicitly that indigenous peoples are entitled to the recognition of the full ownership and protection of their cultural and intellectual property. The bottleneck is, however, that cultural and intellectual property rights are simultaneously eroded by the TRIPS agreement.

\section{PACIFIC STRATEGIES FOR THE PROTECTION OF CULTURAL AND INTELLECTUAL PROPERTY RIGHTS}

When indigenous claims of cultural and intellectual property were first articulated, they were soon dismissed as incompatible with existing intellectual property legislation. Brown, for example, argued that indigenous expressions of knowledge cannot be ascribed to one identifiable inventor, and the cultural heritage of indigenous people is usually much older than is allowed within the scope of intellectual property legislation ( 50 or 70 years). ${ }^{17}$ Indigenous claims to stop others from using their heritage are also contradictory to the purpose of intellectual property legislation that aims at making knowledge available in the public domain. ${ }^{18}$ These contradictions are further compounded by the expansion of the concept of intellectual property to cultural property as though the law would recognize originality in a broad sense, which it does not. ${ }^{19}$

Indigenous peoples throughout the world, however, have not been discouraged by the limitations of Western legislation to protect their cultural heritage. ${ }^{20}$ They have responded that their right to control traditional knowledge is primarily a right of self-determination, which is embedded in the Declaration on the Rights of Indigenous Peoples. In the Pacific this right was further specified in the Mataatua Declaration on Cultural and Intellectual Property Rights of Indigenous Peoples, which was signed by delegates from 14 countries in New Zealand as early as 1993. At the same time, indigenous peoples began developing new strategies to safeguard their heritage, for which they have been receiving support from international organizations, such as UNESCO and especially the World Intellectual Property Organization (WIPO). In 1999 WIPO examined the relationship between intellectual property rights and traditional knowledge, after which it established the Intergovernmental Committee on Intellectual Property and Genetic Resources, Traditional Knowledge and Folklore. The aim of this committee is to develop guidelines concerning the protection of traditional knowledge and expressions of culture against misappropriation and misuse. This objective, in turn, is linked to the effort to develop special legal mechanisms, generally known as sui generis legislation, to protect traditional cultural expressions.

Recent initiatives of WIPO's Intergovernmental Committee have resulted in special provisions for the protection of traditional knowledge and cultural expressions against misappropriation around the world. In the Pacific area it has even led to the development of a so-called Model Law to promote sui generis legisla- 
tion for the protection of their cultural heritage. The Pacific Model Law was designed by the Secretariat of the Pacific Community (SPC), comprising 26 Pacific Island countries and territories (PICTs). In 2002 it adopted a Regional Framework for the Protection of Traditional Knowledge and Expressions of Culture to stimulate and guide the development of national legislation for the protection of cultural and intellectual property that has been transmitted over generations and is also held in collective ownership. The objective is to protect the rights of traditional owners in their traditional knowledge and expressions of culture (TKECs), permit tradition-based creativity and innovation, including commercialization, ensure that the use of TKECs always takes place with the prior informed consent of the traditional owners, and finally, ensure the sharing of benefits derived from the use of TKECs. ${ }^{21}$ The Pacific Model Law recognizes that a universal template to protect TKECs does not accommodate national priorities and the needs of local communities. Instead, a holistic approach is taken to enable national governments to develop policy solutions and legislation that fit within and complement the regional framework.

\section{THE CONTRIBUTIONS}

The development of a Model Law by the Secretariat of the Pacific Community demonstrates that in the Pacific region the drive to protect cultural and intellectual property has gathered its own momentum, in spite of the legal barriers in Western intellectual property legislation that were identified as important impediments at the beginning of the discussion some 15 years ago. This precisely makes the contributions to this special issue highly topical. The first article by Jo Recht, who has been trained in law as well as in anthropology, presents an overview of the contemporary context in which indigenous peoples and multinational organizations have pursued the objective of "protecting indigenous knowledge"; at the same time, it addresses some of the theoretical and practical questions such protection raises. Recht examines the debate with particular attention to its hegemonic overtones and argues that anthropological analysis and insight is invaluable in informing the development of the various frameworks of protection so that they will enhance rather than undermine the cultural diversity they are designed to protect. Her argument is illustrated with reference to the work of the Pacific Community and the government of Fiji in trying to develop sui generis protection frameworks for their indigenous cultural knowledge, Fijian pottery designs especially.

Guido Pigliasco extends the debate initiated by Recht from—tangible—pottery to the-intangible-firewalking ceremony traditionally performed only by members of a certain clan in Fiji. With an increasing numbers of tourists visiting Fiji, however, firewalking has become a commodified symbol of the indigenous culture of the entire Fijian archipelago. Pigliasco compares the discussion about the 
appropriation of the firewalking ceremony by the tourism industry to the discussion about the ownership of the nagol in Vanuatu, the land diving originally conducted on Pentecost Island but later also on the island of Espiritu Santo. Both land diving and firewalking are traditional forms of culture that constitute potent ethnic markers for local groups, but their performances became also popular among other neighboring groups with the growth of tourism, which generated a debate about the ownership of intangible cultural property. The originators of the firewalking ceremony in Fiji began a project in collaboration with Guido Pigliasco, an Italian lawyer with a doctorate in anthropology from the University of Hawail $i$, to protect their cultural heritage by documenting their cultural heritage in DVD format. The production of a multimedia tool aims at the legal protection of indigenous practices under the auspices of the Great Council of Chiefs, which is also involved in the implementation of the Pacific Model Law in Fiji.

The discussion about the ownership of the firewalking ceremony in Fiji brings to light a structural difference between traditional principles regarding the ownership of traditional knowledge and practices on the one hand, and Western regimes for the protection of intellectual property on the other. First, it is incorrect to assume that non-Western societies were traditionally unfamiliar with mechanisms for the protection of cultural or intellectual property. Robert Lowie, for example, described a range of compelling examples of what he labeled "incorporeal property" among "primitive peoples" who sometimes see stories, dances, myths, magical rites, or even dreams as the exclusive property of individuals. ${ }^{22}$ Second, it is misleading to refer to Western intellectual property legislation for the protection of cultural property, because it has also been used for the expropriation and legal alienation of traditional knowledge. The latter point is demonstrated by James Nason, an American professor of anthropology, and Joakim Peter, the director of the Chuuk Campus of the College of Micronesia in the Federated States of Micronesia. They discuss the conflict between indigenous and so-called nonindigenous law in Micronesia, especially on Chuuk (formerly Truk), but they also compare this clash of cultures in relation to contemporary Native American intellectual property issues and tribal responses for the protection of such knowledge and to control research activities by outsiders. Nason and Peter situate their analysis of the commodification and misappropriation of traditional knowledge in Micronesia within the wider discussion about the Pacific Model Law, and they finish with the recommendation of specific steps to be taken to protect cultural heritage.

Shifting the discussion to Melanesia, Lamont Lindstrom examines the complicated debate about the use and abuse of kava. In the 1990s global interest in the recreational and therapeutic use of kava peaked, but at the same time concerns emerged over bioprospecting or even biopiracy of the plant. Bioprospecting refers to scientific investigations of new medical uses of plants and animals, whereas biopiracy is used to describe the appropriation or misappropriation of flora and fauna by pharmaceutical and other commercial industries. Given its popularity 
around the globe, kava was under serious risk of appropriation by multinational pharmacological corporations, which in the Pacific generated claims to kava as cultural property by Vanuatu as well as by Fiji. Kava piracy narratives, however, became more complicated when in 2001 Germany and later a range of other Western countries banned sales of kava products following reports of liver damage among heavy users. The kava export market collapsed, and the discourse of kava as the cultural property of Pacific societies shifted to a debate about new marketing strategies to recapture the recreational market for kava. In this context, producers of kava began labeling the place of origin in analogy with winemakers and, more recently coffee brewers, all attempting to highlight the so-called noble varieties of their products, in this case: kava. Thus, it is hoped that by situating the plant within its terroir, it would be more difficult to pirate.

Andrew Moutu also provides a contribution on the basis of ethnographic research in Melanesia, more specifically his home area the Sepik in Papua New Guinea. He aims at highlighting the differences between Western and Melanesian modes of thinking about culture, creativity, and ownership. Moutu participated in the Cambridge project initiated by Marilyn Strathern, entitled "Property, Transactions and Creations: New Economic Forms in the Pacific," ${ }^{23}$ which aimed to produce knowledge of the social relations in which ownership claims are made. It tried to reveal the principles whereby transactions of ownership make explicit claims to the creative input of various kinds in actual resources. Against this background, Moutu outlines a dialectical contrast between, on the one hand, the linear logic of Western forms of creativity and, on the other hand, the analogical forms of creativity in Melanesia. In Western societies people generally own what they create, whereby ownership functions as a mechanism to enhance and stimulate further creativity. In Melanesia, by contrast, people generally create what they own; thus, creativity functions as a mechanism to perpetuate ownership. Moutu substantiates his argument with an ethnographic case study from a Iatmul village in the Sepik, where two kin groups have been contesting the rights to use a particular fishing lagoon created by redirecting the banks of the Sepik River. One group claimed the lagoon because it had created it, but the other group opposed the claim on grounds that they own the names connected to the land on which the lagoon was created. Moutu relates this discussion to the introduction of trademarks in Papua New Guinea, which enables him to illustrate Strathern's conception of land as intellectual property.

Michael Goldsmith extends Moutu's discussion of incompatible claims of cultural and intellectual property in Melanesia to New Zealand, where property rights are also inflected by a number of crosscutting issues, questions, and tensions. Goldsmith revisits and revises Michael Brown's original question "Who Owns Native Culture?" by posing the question "Who Owns Native Nature?" in his investigation of the overlaps and tensions between nature and culture in theoretical, legal, and political discourses. The relation between nature and culture is interpreted and understood in a radically different way by the indigenous people of New Zealand, 
Māori, and descendants of the predominantly European settlers of the country, referred to as Pākehā by Māori. The tense relationship between Māori and Pākehā is characterized by judicial procedures and constitutional settlements put in place to mediate between Māori tribes and the Crown. Over the last 30 years, these procedures have generally been channeled through the Waitangi Tribunal, but some particularly contentious issues have been removed from the judicial sphere. The debate over rights to the foreshore and seabed is the most prominent issue and constitutes the main empirical focus of Goldsmith's article. He explores the differences and similarities between various property rights and the legal regimes that are brought to bear on them, the cultural similarities and differences that are referred to as the basis for some of the conflicts and settlements between the settler and indigenous populations (i.e., individualism and secularism versus collectivism and spirituality), and the tacit theoretical underpinnings of claims to property rights that have discernible links to the contrasting philosophical positions known as realism and social constructionism.

Finally, Toon van Meijl also addresses and contextualizes the emergence of a discourse of cultural and intellectual property rights in Māori society. Since the establishment of the Waitangi Tribunal in 1975, and even more since 1985 when the jurisdiction of the Waitangi Tribunal was backdated to 1840, not only lands, forests, and fisheries have been claimed back under the terms of the treaty, but also a variety of nonmaterial objects, such as language and an equitable share of the airwaves to be able to broadcast Māori programs on New Zealand radio and television. These claims have been acknowledged because in the Māori version of the Treaty of Waitangi the concept of taonga or treasure was included in the clause protecting Māori chieftainship over their "lands (and) villages." Earlier submissions to the Waitangi Tribunal have successfully contended that taonga refers to all dimensions of a tribal group's estate, material and nonmaterial.

Van Meijl analyzes the discourse of cultural and intellectual property in the context of the problematic and paradoxical relationship between Māori and Pākehā in postcolonial New Zealand. Following Simon Harrison, ${ }^{24}$ he argues that Māori claims regarding intellectual property also function to reinforce ethnic boundaries between Māori and Pākehā. Māori consider the demarcation of ethnic boundaries necessary because they experience their society and distinctive way of life as endangered both by the foreign consumption or misappropriation of aspects of their authentic cultural forms and by the intrusion of foreign cultural elements. The first threat is often represented as an undesired form of cultural appropriation, piracy or theft, whereas the second threat is viewed as a form of cultural pollution. This argument is elaborated with a case study of each so-called danger, namely a claim regarding six species of native flora and fauna submitted to the Waitangi Tribunal, which is considered an example of resistance against cultural appropriation, and the increasing hostility of Māori to foreign interest and research in Māori culture and society, which is analyzed as an example of opposition to putative pollution. 
In sum, these articles address the discourse of cultural and intellectual property rights in the Pacific region in its full complexity. The holistic and anthropological approach that is underlying all contributions to this special issue enables the authors to reflect on the social and political tension that is not only provoking indigenous policies for the protection of traditional knowledge and expressions of culture against misuse and misappropriation by others, but which is reinforced by these policies at the same time. Thus, it is also hoped that this special issue may make a contribution to the further development of indigenous strategies for the protection of their cultural traditions without simultaneously strengthening the ethnic inequalities that are triggering indigenous discourses of cultural property in the first place, not only in the Pacific but around the globe.

\section{ENDNOTES}

1. Coombe, The Cultural Life of Intellectual Property.

2. Kaneff and King, "Owning Culture."

3. Appadurai, Globalization.

4. Brown, "Heritage as Property."

5. Harrison, "Cultural Boundaries" and Fracturing Resemblances.

6. Compare Striphas and McLeod, "Strategic Improprieties."

7. Hastrup, "Representing the Common Good."

8. Compare Fabian, "Religious and Secular Colonization," 341.

9. Goodenough, "Oceania and the Problem of Controls."

10. Denoon and colleagues, The Cambridge History.

11. For example, Cowan, Dembour, and Wilson, Culture and Rights, Rowlands, "Cultural Rights and Wrongs," and Wilson and Mitchell, Human Rights in Global Perspective.

12. Clifford, "Looking Several Ways," 6.

13. Kirsch, "Lost Worlds."

14. Brush, "Indigenous Knowledge," Greaves, "Tribal Rights," and Posey, "International Agreements."

15. Arewa, "TRIPS and Traditional Knowledge."

16. For example, Mead and Ratuva, Pacific Genes.

17. Brown, "Can Culture Be Copyrighted?"

18. Brown, Who Owns Native Culture?

19. Strathern, "Potential Property," 23; and Strathern, Property, Substance and Effect.

20. Coombe, "Protecting Cultural Industries."

21. Pacific Community, Guidelines for Developing.

22. Lowie, Primitive Society, 235-43.

23. For example, Strathern, "Rationales of Ownership," and Hirsch and Strathern, Transactions and Creations.

24. Harrison, "Cultural Boundaries."

\section{BIBLIOGRAPHY}

Appadurai, Arjun, ed. Globalization. Durham: Duke University Press, 2001.

Arewa, Olufunmilayo B. “TRIPS and Traditional Knowledge: Local Communities, Local Knowledge and Global Intellectual Property Frameworks." Marquette Intellectual Property Law Review 10, no. 2 (2006): 156-80. 
Brown, Michael F. “Can Culture Be Copyrighted?” Current Anthropology 39, no. 2 (1998): 193-222. . "Heritage as Property." In Property in Question: Value Transformation in the Global Economy, edited by K. Verdery and C. Humphrey, 49-68. Oxford: Berg, 2004.

Who Owns Native Culture? Cambridge, MA: Harvard University Press, 2003.

Brush, Stephen B. "Indigenous Knowledge of Biological Resources and Intellectual Property Rights: The Role of Anthropology.” American Anthropologist 95, no. 3 (1993): 653-71.

Clifford, James. "Looking Several Ways: Anthropology and Native Heritage in Alaska." Current Anthropology 45, no. 1 (2004): 5-30.

Coombe, Rosemary J. The Cultural Life of Intellectual Properties: Authorship, Appropriation and the Law. Durham: Duke University Press, 1998.

. "Protecting Cultural Industries to Promote Cultural Diversity." In International Public Goods and Transfer of Technology Under a Globalized Intellectual Property Regime, edited by K. Maskus and J. Reichman, 559-614. Cambridge: Cambridge University Press, 2005.

Cowan, Jane K., Marie-Bénédicte Dembour, and Richard A. Wilson, eds. Culture and Rights: Anthropological Perspectives. Cambridge: Cambridge University Press, 2001.

Denoon, Donald, with Stewart Firth, Jocelyn Linnekin, Malama Meleisea, and Karen Nero, eds. The Cambridge History of the Pacific Islanders. Cambridge: Cambridge University Press, 1997.

Fabian, Johannes. "Religious and Secular Colonization: Common Ground." History and Anthropology 4 (1990): 339-55.

Goodenough, Ward H. "Oceania and the Problem of Controls in the Study of Cultural and Human Evolution.” The Journal of the Polynesian Society 66, no. 2 (1957): 146-55.

Greaves, Thomas. “Tribal Rights.” In Valuing Local Knowledge: Indigenous People and Intellectual Property Rights, edited by S.B. Brush and D. Stabinsky, 25-40. Washington: Island Press, 1996.

Harrison, Simon. “Cultural Boundaries.” Anthropology Today 15, no. 5 (1999): 10-13.

Fracturing Resemblances: Identity and Mimetic Conflict in Melanesia and the West. New York: Berghahn, 2006.

Hastrup, Kisten. "Representing the Common Good: The Limits of Legal Language." In Human Rights in Global Perspective: Anthropological Studies of Rights, Claims and Entitlements, edited by R.A. Wilson and J.P. Mitchell, 16-32. London: Routledge, 2003.

Hirsch, Eric, and Marilyn Strathern, eds. Transactions and Creations: Property Debates and the Stimulus of Melanesia. New York: Berghahn, 2004.

Kaneff, Deema, and Alexander D. King. “Owning Culture.” Focaal: European Journal of Anthropology 44 (2004): 3-19.

Kirsch, Stuart. "Lost Worlds: Environmental Disaster, 'Culture Loss' and the Law." Current Anthropology 42, no. 2 (2001): 167-98.

Lowie, Robert H. Primitive Society. New York: Liveright, 1947.

Mead, Aroha Te Pareake, and Steven Ratuva, eds. Pacific Genes and Life Patents: Pacific Indigenous Experiences and Analysis of the Commodification and Ownership of Life. Wellington: Call of the Earth 
(Llamado de la Tierra) and Institute of Advanced Studies, United Nations University, 2007. Available at http://www.ias.unu.edu/sub_page.aspx?catID $=97 \& d d 1 \mathrm{ID}=229$ (accessed 25 October, 2009).

Pacific Community, Secretariat of the. Guidelines for Developing National Legislation for the Protection of Traditional Knowledge and Expressions of Culture Based on the Pacific Model Law 2002. Noumea: Secretariat of the Pacific Community, 2006.

Posey, Darrell A. "International Agreements and Intellectual Property Right Protection for Indigenous Peoples." In Intellectual Property Rights for Indigenous Peoples, edited by T. Greaves, 223-51. Oklahoma City: Society for Applied Anthropology, 1994.

Rowlands, Michael. "Cultural Rights and Wrongs: Uses of the Concept of Property." In Property in Question: Value Transformation in the Global Economy, edited by K. Verdery and C. Humphrey, 20726. Oxford: Berg, 2004.

Strathern, Marilyn. "Potential Property: Intellectual Rights and Property in Persons." Social Anthropology 4, no. 1 (1996): 17-32. lone, 1999.

Property, Substance and Effect: Anthropological Essays on Persons and Things. London: Ath-

"Rationales of Ownership." In Rationales of Ownership: Transactions and Claims to Ownership in Contemporary Papua New Guinea, edited by L. Kalinoe and J. Leach, 1-12. Wantage, UK: Sean Kingston, 2004.

Striphas, Ted, and Kembrew McLeod. "Strategic Improprieties: Cultural Studies, the Everyday and the Politics of Intellectual Properties." Cultural Studies 20, no. 2-3 (2006): 119-44.

Thompson, E.P. “The Long Revolution.” New Left Review no. 9-10 (1961): 24-39.

Wilson, Richard Ashby and Jon P. Mitchell, eds. Human Rights in Global Perspective: Anthropological Studies of Rights, Claims and Entitlements. London: Routledge, 2003. 